\title{
Closed mouth method with dynamic and muco compressive impression on upper and lower jaw flat ridges for aid full denture retention
}

\author{
Utari Kresnoadi and Rostiny \\ Department of Prosthodontic \\ Faculty of Dentistry Airlangga University \\ Surabaya - Indonesia
}

\begin{abstract}
A patient with flat ridge difficult to have retentive complete denture. The aim of this paper is to describe the combination of impression using closed mouth technique with dynamic and muco compressive material. In this case, the combination technique of dynamic impressive material and muco compressive material with closed mouth method on patient with upper and lower jaw flat ridges. The patient has made complete denture 10 times but not satisfied. The treatment of upper and lower flat ridges using this technique resulted retentive, stable and comfortable denture.
\end{abstract}

Key words: closed mouth method, dynamic and muco compressive impression, flat ridge

Correspondence: Utari Kresnoadi, c/o: Bagian Prostodonsia, Fakultas Kedokteran Gigi Universitas Airlangga. Jln. Mayjend. Prof. Dr. Moestopo no. 47 Surabaya 60132, Indonesia.

\section{INTRODUCTION}

Patient with flat ridge really needs full or complete denture for the purpose of chewing, speaking and improving the appearance. A dentist is considered successful to make a complete denture if the result is stable, retentive and comfortable to be used. Hamada et al. ${ }^{1}$ suggested that the number of complete denture users would increase due to the increasing number of elderly people.

Left ridge resorption would occur in patient with prolonged tooth which are left untreated and are not replaced by denture and the ridge has functioned to chew the food. Ridge resorption would also occur in patient with prolonged denture due to continuous pressure on the ridge while patient is chewing the food and it could cause resorption on the alveolar ridge bone as a result the bones becomes flat and, further, the mandible would be anthropy. It is also suggested by Hamada et al. ${ }^{1}$ that after using prolonged complete denture, the space between denture base and soft tissue would be larger because of the increase resorption of alveolar bone.

The early stage of resorption of residual ridge is initiated by the loss of the tooth and periodontal membrane which is capable to form the bone. The disappearance of alveoli could occur in labio lingual and vertical direction, so the ridge would be narrower. In some cases the ridge could be sharp like a knife or knife edge and shortening. Further, procesus alveolaris would below, rounded or flat. If the resorption process continues resulting in disappearance of basal bone and followed by shortening ridge in oral cavity. $^{2}$

Accurate impression is needed to make complete denture if it is followed by flat alveolar ridge. Denture impression were once made without regard to the muscular function involved. Plaster, wax or gutta percha was used without muscle trimming in order to gain an impression of the basal seat. ${ }^{3}$ Further, mucustatic impressive material which could record the jaw without distortion and procedure mucosal impression in detail. In twentieth century, impression with compression and inv@llving functional muscle trimming is started to be applied.

To make a complete denture, impression with "making impression" mold is needed by preparing two impressions: mucostatic and muco compressive impressions. To impress using mucostatic, fabricated stock tray with hole with mucostatic impressive material is used. ${ }^{4}$ This material must be mixed with water, before it is used. ${ }^{3}$ The anatomical model of patients jaw is obtained from the impression in which. further, would be made for patients individual tray. ${ }^{4}$

Individual tray is made before making impression using muco compressive material then continued by border molding which gives compound material on the edge of individual tray to get the form of pheripheal seal which is useful for denture's retention. Some experts ${ }^{3,5}$ made impression using muco compressive impression material to achieve accurate impression in case of lower jaw flat ridge.

In case of lower jaw alveolar flat ridge, retention could be achieved by making additional retention on mandible that is the extension of retromylohyoid region by scarping the part of anatomy model so that individual tray in the region could be longer, it is also possible by adding compound material during molding. ${ }^{4}$ Molding in retromyloyoid region, when it is seen laterally, it forms the letter " $S$ " but it is seen from above, it would form butterfly wing. ${ }^{6}$ 
The principe of impression by using compression is to achieve well basis mucos on ridge, with light compression on the upper most ridge and to cover submucosal tissue. ${ }^{3}$ There are two methods of impression with compression those are: open and closed mouth. Mostly open mouth method is more preferred because the operator can easyly trim the muscle and see the movement. While in close mouth method first the bite occlusion should be determine in wax. ${ }^{3}$ The tongue movement is stronger during occlusion when the mouth is closed simultaneously, and also there is no other power to disturb ridge when the jaw is closed in occlusal centric condition. Some experts ${ }^{1,7}$ suggested that closed moth technique with tissue conditioner/soft liner as dynamic impression material could make the same mouth movement producing good impression because the material could fungsionally distribute the movement on the surface of basal tissue on elderly patient. Impression with closed mouth could develop physiological strength of muscle trimming during border molding the impression could record the compressed soft tissue to achieve good outcome, in this technique, patient's cooperation is really needed. ${ }^{8}$

The purpose of this paper is to combine between dynamic and muco compressive impression material with closed mouth technique in patient with lower and upper jaw flat ridges as an effort to did retention of complete denture of upper and lower jaw.

\section{CASE}

A 70 year old female patient, a mandarin tutor, lost her teeth due to caries and extracted. She also suffered from diabetes mellitus and used a removable denture since she was 35 years old. The patient used ten times of dentures in which five times made by dental technician and five times made by a dentist. The denture was replaced due to pain and unfit and alveolectomy was ever done.

The condition of mouth cavity: The conditions which were found: edentulous flat ridge in upper and lower jaw, shallow vestibulum, the height of ridge less than $1 \mathrm{~mm}$ in

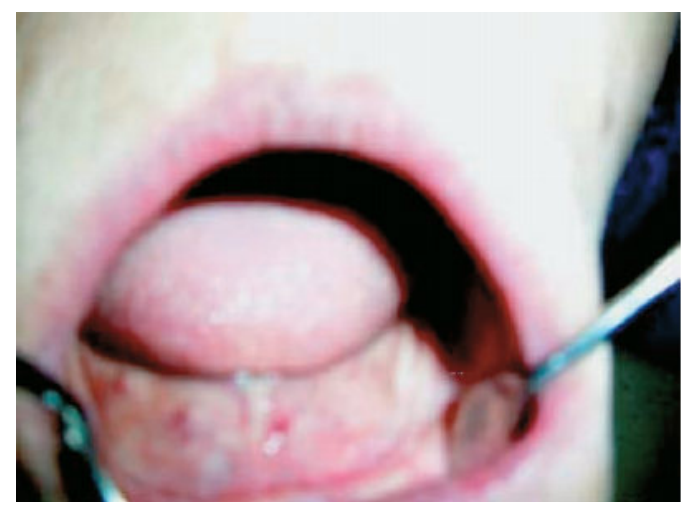

Figure 1. Lower jaw flat ridge.

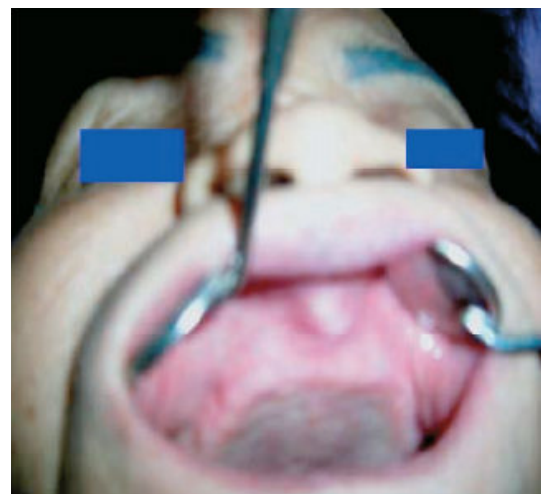

Figure 2. Upper jaw flat ridge.

lower jaw (Figure 1) and $2 \mathrm{~mm}$ in upper jaw (Figure 2). Flat torus mandibularis, low frenulum ridge relation either the transversal or the front was normal. The treatment plan for this patien was: complete denture of upper and lower jaws could be made using closed mouth technique.

\section{CASE MANAGEMENT}

Impression with closed mouth technique was done because the patient had resorption/upper and lower jaw flat. Mucostatic impression with alginate material was initially done on the patient, using this impression model anatomy was obtained, then denture outline was made and it is very essential part in this stage in order to avoid "over extension" (Figure 3). In this case wax spacer was not necessarily done due to the condition of flat ridge then, individual tray of self cured acrylic material was made.

Further, muco compressive impression using silicon rubber base impressive material was done on the patient. The result of mucopressive impression of upper and lower jaws could seen in Figure 5. From the working cast acrylic base with bite wax made the height and bite position were searched and fixated (Figure 6).

The next step, dynamic tissue conditioner/softliner impressive material was placed on acrylic base and impression with closed mouth method was carried out, by returning fixated bite wax into the mouth using tissue
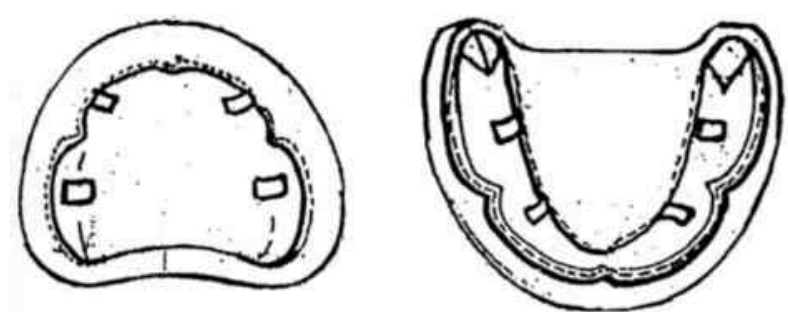

Figure 3. Outline process of individual tray RA \& RB Border moulding was done individual tray with compound material to get peripheal seal (Figure 4). 


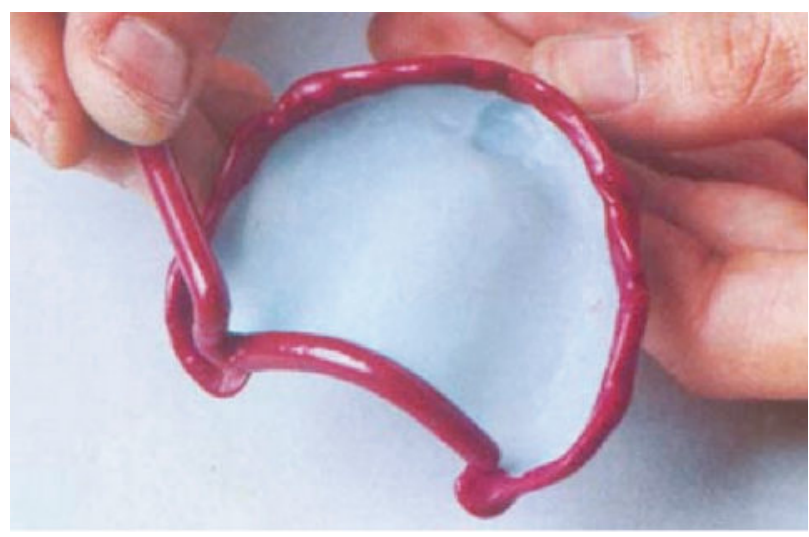

Figure 4. Giving compound material for border moulding. ${ }^{5}$
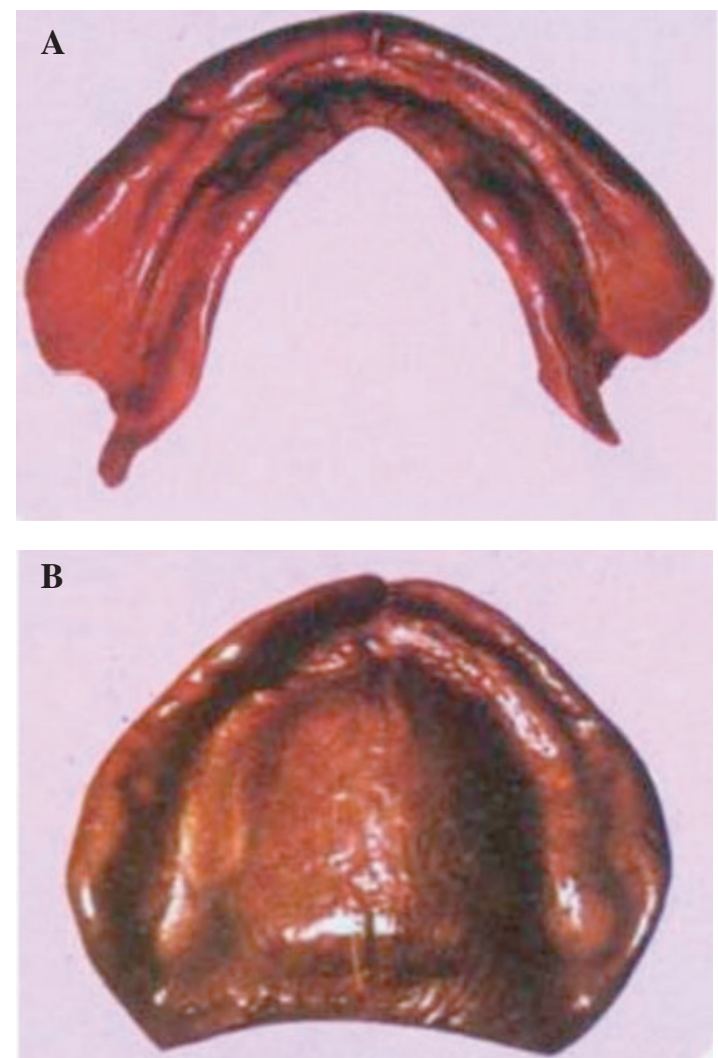

Figure 5. The result of muco compressive impression of upper (B) and lower (A) jaws. ${ }^{5}$

conditioner material as functional impression material which would functional distribute stress on the basal tissue surface. The result of compressive with closed mouth method using tissue conditioner/soft lining material could seen in Figure 7.

Then the muco compressive/elastomer impression material was given on tissue conditioner impression. Impressing process with closed mouth method using compressive material by returning bite wax fixated into the mouth (Figure 8). And the result could seen in Figure 9.

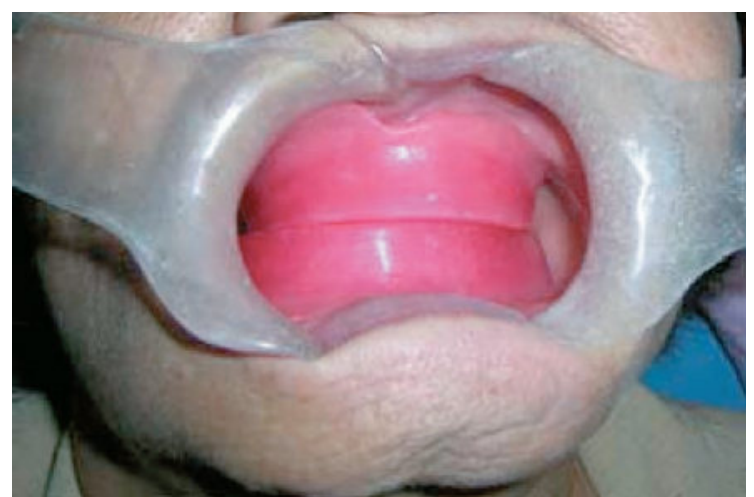

Figure 6. Searching the height and bite position.

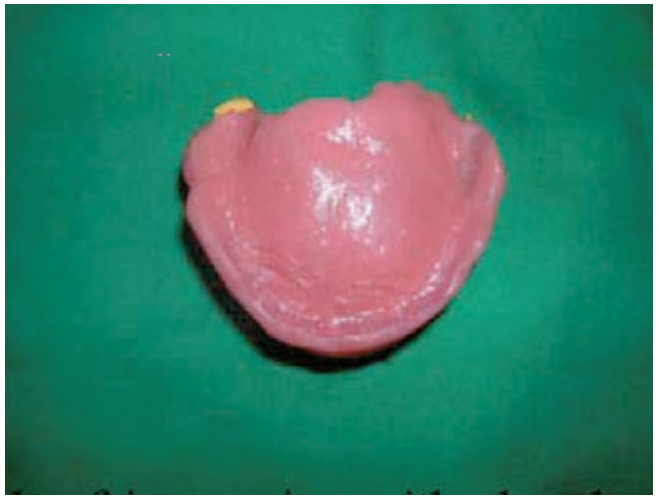

Figure 7. The result of impression with closed mouth method using tissue conditioner/softliner material.

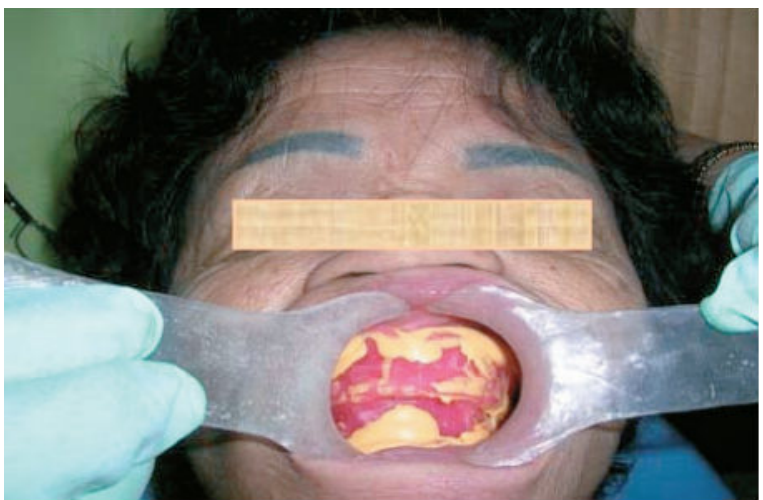

Figure 8. Impressing process with closed mouth method using muco compressive material.

The process was continued by filling with hard gypsum and working model was formed and put on articulator. The following step, teeth arrangement was done and adjusted on the patient. Teeth arrangement should be on the tip of ridge netral zone (Figure 10). Over bite and overjet of anterior teeth should be paid. Closed attention as well as curve of Spee should be seen from sagital side and curve of monson of transversal side of posterior tooth arrangement. 


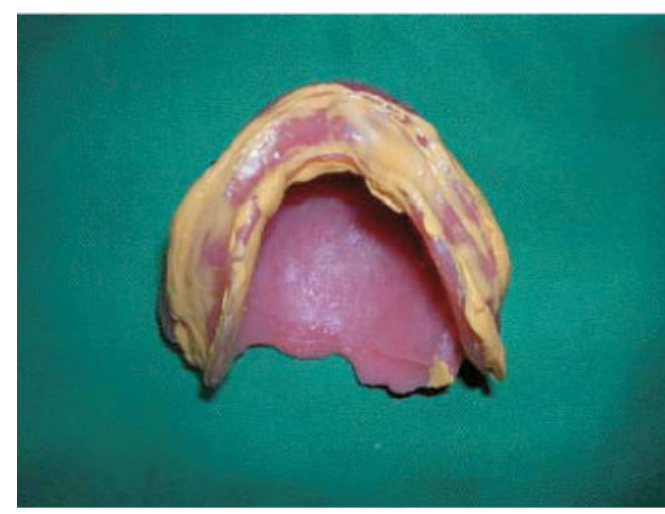

Figure 9. The result of closed mouth technique with muco compressive material.

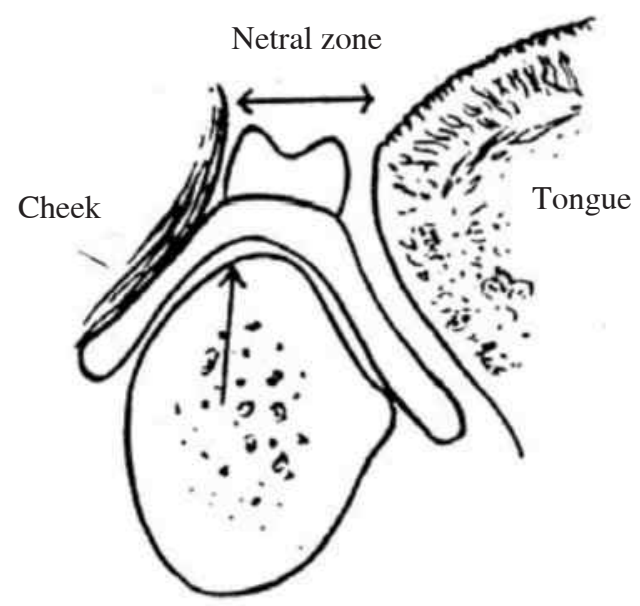

Figure 10. Netral zone. ${ }^{9}$

The adjustment was tried on the patient in the condition that wax was still used. If the patient was satisfied with denture wax, then, countour would be done. Followed by acrylic processing and polishing. The next step, acrylic denture was adjusted on the patient. Occlusal record was done for occlusal correction (Figure 11), then continued by selective grinding, polishing and the last, it would be applied on the patient.

The instructed given to the patient after the denture was insertion that was: denture was allowed only for drinking and speaking, but not eating. The denture was recommended used at night and followed up on the one day.

The first day of follow up control, the patient complained of pain in mylohyoid region and lingual region of anterior lower jaw. In fact, the pain was caused by excessive pressure of denture, therefore, grinding was done in retromylohyoid region and lingual part of anterior denture. The upper jaw seemed retentive and no complaint presented by the patient.

Next, the patient was advised to use the denture to eat something soft, to drink and to speak. The denture should be removed at night and soaked in water, with the purpose

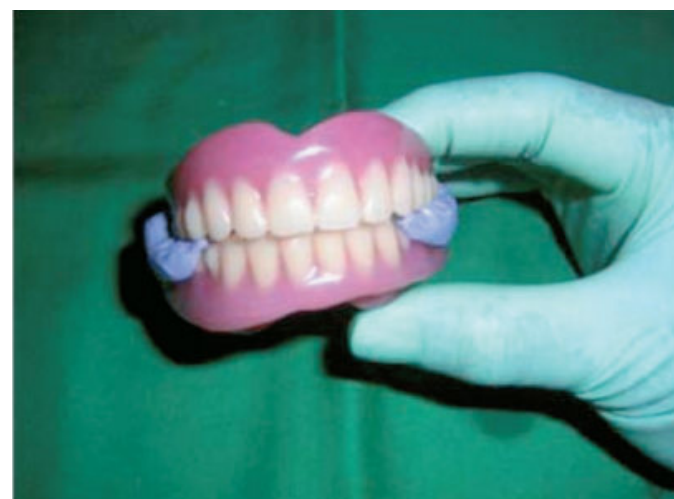

Figure 11. The result of intermaxilary record seen frontally.

that the tissue would rest. The patient was instructed to have follow up control three days later.

On the second day followed up, the condition of upper and lower jaw denture was stable and retentive, but, the patient still complained of pain in lingual region of anterior lower jaw, because of excessive pressure from denture. To reduce the pain, anterior lingual region was grinded, but not excessively in order not to reduce denture retention. The patient was advised to have follow up control the following week. The instruction was similar to first control. On the third follow up control, the patient still complained of pain in anterior lingual lower jaw, but the complete denture was retentive and stable so grinding was done, slightly reducing part of lingual anterior and polishing, the instruction was still similar to the second control if there was any complaint, the patient was advised to have regular control.

The patient came to control two months after insertion, without complaint, the denture was retentive and stable. The patient felt comfortable to use complete denture either for speaking or chewing the food, the patient felt satisfied. The patient was suggested to come for control periodically six months after the usage of denture.

\section{DISCUSSION}

In this case, as the procedure of complete denture can not be done by increasing other retention such as: tooth implantation, therefore, accurate method of impression must be done so the space between denture and basal seat would be vacuum, air pressure would be less than $1 \mathrm{~atm}$, denture would become retentive and stable. De Franco and Sallustio $^{8}$ also confirmed that if another treatment such as: implant denture could be not be applied in the case of atrophied mandible, therefore, supporting denture is only on the residual tissue such as: mucosa and ridge, so procedure of impression is made for atrophied mandible.

Hamada et al. ${ }^{1}$ suggested that it is not easy to produce good jaw impression in elderly patient who is toothless, dynamic impression would produce better outcome. In impression with closed mouth method, impression with soft liner/tissue conditioner material is initially done 
because by using this material good pheriperal seal could be achieved and could balance mucosa reciliancy. In this case, it is similar to the opinion of Hamada et al. ${ }^{1}$ that impression using closed mouth technique with dynamic impressive material is conducted in order to be able to make equal mouth movement. In other words that the result of impression is obtained from patient's mouth movement with tissue conditioner material.

The some opinion also showed by Chase and Starcke cit. Abdul Razek, ${ }^{8}$ that tissue conditioner material is functional impression material. Functional impressive material is one of materials which is used on the surface of basal seat of denture which makes functional stress distribution or this material makes the surface of basal seat tissue and border tissue of denture recorded when it is functional.

The patient had really flat ridge due to prolonged use of denture for more or less thirty five years. To Increase retention, impression with muco compressive material is required to be able to compress the mucosa so it could produce accurate impression. In this way, vacuum space between mucosa and denture would be achieved. Itjingsih ${ }^{9}$ and Zarb et al. ${ }^{10}$ indicated the same opinion that impression with muco compression is needed to make the compression more equal, impression material could flow and fill complicated part, so it could impress accurately.

In this case, after using complete denture, the patient felt her denture was retentive, stable and comfortable to be used comparing with her ten denture ago. Even though she felt pessimistic at the beginning to have complete denture in mouth considering the ridge was flat. After using the new complete denture, the patient felt satisfied and she could chew the food, speak normally and she has better performance.

It is concluded that to make a complete denture in the management of that flat ridge case on upper and lower jaw, it is needed to apply impression using closed mouth technique with dynamic (tissue conditioner/soft liner) and muco compressive to get retentive and stable.

\section{REFERENCES}

1. Hamada T, Murata H, Razak A. Pelapisan gigi tiruan, denture lining. Cetakan I. Surabaya: Airlangga University Press; 2003. p. 48-52.

2. Nishimura I, Hosokawa R, Attwood DA. The knife edge tendency in mandibular ridge in women. J Prosthet Dent 1992; 67:820-6.

3. Sharry J. Complete denture prosthodontic. $3^{\text {rd }}$ ed. New York, St Louis, Toronto: McGraw-Hill Book Co; 1974. p. 200-3.

4. Kresnoadi U. Cara menanggulangi goyangnya gigi tiruan pada waktu mengunyah. Buku Ceramah Ilmiah, Surabaya Dentistry 2003; 2003. p. 8.

5. Rita IU, Widyana H. Disain dan tehnik mencetak pada pembuatan geligi tiruan lengkap. Ceatakan 1. Jakarta: Hipokrates; 1994. p. 43.

6. Heartwell CM, Rhan AO. Syllabus of complete denture. $4^{\text {th }}$ ed. Philadelphia: Lea \& Febiger; 1986. p. 178-83.

7. Abdel Razek MA. Assesment of tissue conditioning materials for functional impression. J Prosth Dent 1978.

8. De Franco RL, Sallustio A. An impression procedure for severely atrophied mandible. J Prosthet Dent 1995; 73:574-7.

9. Itjiningsih WH. Geligi tiruan lengkap lepas. Cetakan ke-3. Jakarta: Penerbit Buku Kedokteran/EGC; 1996. p. 26, 39.

10. Zarb GA, Bolender CL, Hickey JC, Carlson GE. Bouchers prosthodontic treatment for edentulous patients. $7^{\text {th }}$ ed. St Louis, Baltimore, Philadelphia. 1990. p. 197-210. 